\title{
ECONOMIC IMPLICATION OF CONTRACT FARMING ON SMALL-SCALE RICE FARMERS IN KWARA STATE, NIGERIA
}

\author{
*Akanbi, S.O, Alarape, W.I, and Olatunji, O.S \\ Department of Agricultural Economics and Farm Management \\ University of llorin, llorin, Nigeria. \\ *Corresponding Author: dipoakanbi@yahoo.com
}

\begin{abstract}
This study examines the implication of contract farming on Olam Out-growers farming scheme in Kwara State, Nigeria. The objectives of the study are to determine the costs and returns to production of rice, assess the productivity level of rice, evaluate the technical efficiency of rice farm and identify the determinants of the technical inefficiency of the rice farms in contract farming. In this study, the average net farm income of the rice farmers under the scheme was A191,862.56 and the land productivity level was 2,006.04kg/ha. The technical efficiency of the rice farm was estimated using Cobb-Douglas Stochastic Frontier Production function which shows that likelihood coefficients for quality of seeds, hired labour and farm size were statistically significant at $1 \%$ level. Likewise, the determinants of technical efficiency among the farmers were household size and farming experience. The results further show that the contract farming scheme has a positive impact on the lives of rice farmers. Therefore, there is a need for partnership with private contract farming outfits in order to improve the current level of access to inputs by rice farmers.
\end{abstract}

Keywords: Contract farming, Out-growers rice farmers, Technical efficiency, Farm income 


\section{INTRODUCTION}

Transformation of agriculture from smallholding to commercial level involves an intermediate expansion of agribusiness sector, linking the agricultural and the manufacturing sectors. The economic institution that is perhaps the most responsible for such an agro-industrial sector is contract farming, it is an indispensable adjunct in modern agriculture, wherein a processing firm contracts the production of 'priority' crop or crops out to smallholder farmers (Du et al., 2013). According to Will (2013), contract farming is regarded as a forward agreement specifying the obligations of farmers and buyers as partners in business, specifying farmers' (sellers') legal obligation to supply the volumes and qualities as specified, and the buyers' (processors'/traders') obligation to off-take the goods and release the payments as agreed and buyers providing embedded services such as: upfront delivery of inputs; pre-financing of input delivery on credit and other non-financial services (e.g. extension, training, transport and logistics).

Contract farming usually follows one of five broad models, depending on the product, the resources of the sponsor (the buyer) and the intensity of the relationship between farmers and sponsors (Eaton and Shepherd, 2001, Da Silva, 2005 and Bijman, 2008). The first type is the centralized model which allows a firm (especially a large processor) to contract a large number of farmers, with strict quality requirements and quantity targets. Prowse (2012) suggested that this model is used for conventional staple crops, in addition to crops with large variations in quality, high-degree of perish-ability, technically difficult production, and a high value-bulk ratio.

The second model is nucleus-estate, where the concerned-firm enters the production through an estate or plantation but also contracts with independent producers. This model is often used for perennial crops and this model preferably used for resettlement or transmigration programmes (Eaton and Shepherd, 2001).

The third model, called tripartite, gives room for a joint venture (between a public entity and a private firm) to enter into a contract with farmers. Eaton and Shepherd (2001) indicated that this model can involve national and/or local government, assuming a form of a public-private partnership (PPP) that is focused on crops with national significance (Prowse, 2012).

The fourth one is referred to as informal model, where smaller firms or traders enter into annual agreements with a limited number of farmers, based on unwritten agreement, which often is on a verbal basis, and much frequently for fruit and vegetables that require minimal processing. As firm size is usually small, the success of such initiatives partly relies on the extent to which other providers (such as the state and/or NGOs) can offer inputs, such as extension and credit (Eaton and Shepherd, 2001) but often suffers from extra-contractual side-marketing due to its non-formal nature. 
The fifth type is the intermediary model where the firm sub-contracts interaction with the farmers to an intermediary, such as a farming committee or a trader. However, the long distance that exist between firm and farm tends to reduce the degree of control that the firm has over the process and the product (Eaton and Shepherd, 2001). The model is always used for staple food crops, and can be adopted successfully in conflict affected countries and fragile states (Prowse, 2012). Contract farming was used for vegetable production in the US, by the seed industry in Europe in the decades before the Second World War (Rehber, 2007), and for pig production in the US immediately afterwards (Hamilton, 2008). Since then, contract farming has expanded to become a significant form of agricultural organization. Rehber (2007) posited that it accounts for around $15 \%$ of agricultural output in developed countries. In East Asia, contract farming is also popular. In China, the government has supported contract farming since 1990 with impressive results: by 2001, over 18 billion hectares were planted under contract-farming arrangements (an increase of around 40\% from the previous year) (Guo et al., 2005, cited in Rehber, 2007).

Sub-Saharan Africa is not left out in contract farming, as the process is also on the increase. While in the late 1980s many contract-farming arrangements had full or partial government ownership (Little and Watts, 1994), most projects are now initiated by the private sector. For example, Swinnen and Maertens (2007) pointed out that in Mozambique almost $12 \%$ of the rural population was involved in contract farming (with all cotton grown through contracts). In Kenya, over $50 \%$ of tea and sugar was produced under contracts, in addition to the large number of contract growers of horticultural exports. Furthermore, crops with successful contract-farming operations include coffee (for example, Kawacom's operation in Uganda - (Bolwig et al., 2009) and tobacco (such as Alliance One's expanding programme in Malawi) (IFAD, 2003, cited in Swinnen and Maertens, 2007).

In the Nigeria's context, this concept is less visible with limited presence of OLAM Nigeria limited in their rice, cotton and ginger 'out growers' schemes, NESTLE SLABMARK for soya bean programmes and British American Tobacco Isheyin Agronomy Limited (BATIAL) for tobacco programme. In all these schemes, there were tremendous increase in the output, gross margin and the net profit for each enterprise as well as improved qualities that met all the international standards criteria (Olomola, 2010). These few examples have encouraged the need for the entrenchment of contract farming in the nation's quest for food self-sufficiency.

Rice is a typical cereal crop that has moved from ceremonial to a staple food in Nigerian homes. There are three rice production environments and their coverage in Nigeria are; rain-fed lowland (having a percentage of 69\%), irrigated lowland (taking up 2.7\%) and rain-fed upland (accounted for $28.3 \%$ ). More than $90 \%$ of Nigeria's rice is being produced by poor resource small-scale 
farmers, while the $10 \%$ of rice production is by corporate/commercial farmers (FAO, 2012). Local varieties of rice cultivated in Nigeria include Ofada rice in the southwest and Abakaliki rice in the southeast. These varieties have been recently embraced by Nigerians. With average yield of 1.2 tonnes per hectare, rice production in Nigeria remains poor when compared with countries such as; India, 2.9; Pakistan, 3.0; China, 6.3; Egypt, 8.1; Vietnam, 4.2 and U.S.A., 7.0 [Food and Agricultural Organisation (FAO), 2012].

Nigeria has large irrigation schemes in some states like Anambra, Kwara, Kogi, Adamawa, Niger, Sokoto, Kebbi, Borno, Bauchi and Benue (FAO, 2012). Rice yield in this scheme is estimated at 3.5 tonnes per hectare compared to the expected potential of 7-9 tonnes of rice per hectare. In the rain-fed lowland environment, rice cultivated is characterized by a low yield range of 1.5-3.0 tonnes per hectare as against an expected potential of 3-6 tonnes per hectare.

According to the United States Department of Agriculture on World Markets and Trade, 2018, Nigeria's local rice production dropped from 2016 to 2018. This drop collaborated the reason for the importation of 3 million metric tonnes of rice in 2018. The report also has it that, since 2016, Nigeria had consistently milled 3.8 million metric tonnes of rice annually which was a reduction from 3.9 million metric tonnes in 2015. The reduction, in turn created an increased dependence on imported rice. Nigeria imported 3 million metric tonnes of rice in 2018 which is 400,000 metric tonnes more than the quantity of the product imported in 2017 (USDAWMT, 2018).

The reports indicate that rice consumption supersede production; with consumption of 6.9 million metric tonnes of rice in 2018, an increase of 0.2 million metric tonnes over the previous year. According to the News Agency of Nigeria (NAN) that in 2017, Nigeria's rice consumption stood at 7.9 million tonnes, while the production rate increased to 5.8 million tonnes per annum from previous 5.5 million tonnes due to the federal government's local production policy.

One of the major private contract farming outfit operating in Nigeria is OLAM international limited (hereinafter referred to as OLAM). It was founded in Nigeria in 1989 but currently headquartered in Singapore. It is a renowned international rice producer and a major licensed rice importer. In 2005 , OLAM began rice production in Benue and Kwara states, processing the rice locally from a government rice mill located in Makurdi, Benue State. In 2006, the United States government, through United States Agency for international Development (USAID), partnered with OLAM to develop a rice value chain model that encourages adoption of improved technologies, building farmer's capacity, commercial linkages to credible market outlets and a strategic public privatepartnership. Through transparent agricultural business logistics and knowledge transfer in rice processing, the partnership is expected to provide direct benefits to rural populations while achieving demonstrable impacts on the rice value chain in Nigeria. OLAM specializes in long- 
grain rice (Mama Gold, a brand common in Nigerian markets, is one of their products) that requires specialized variety of paddies. It's out-grower scheme launched in Benue and Kwara States had about 10,000 out-growers in the two states in 2009. The company provided certified seeds and fertilizer credits, and supported mechanization through partnership with the States. The USAID markets program provided training and supervision of selected farmers while OLAM provided training on good agricultural practices to all out-growers. In partnership with First Bank of Nigeria, OLAM offered out-growers loans for other inputs (herbicides, pesticides and farming tools). The company had an arrangement for transportation rice paddies from smallholder farmers sites for processing in a high quality industrial mill and paid competitive (above market) prices for paddies.

This study therefore sought to assess the implication of contract farming on OLAM out-growers in Patigi and Edu Local Government Areas of Kwara State. Specifically, the study;

- determined the costs and returns to production of rice by Out-growers farmers;

- assessed the productivity level of rice;

- evaluated the technical efficiency of the rice farm; and

- identified the determinants of the technical inefficiency of the rice farms.

\section{METHODOLOGY}

The study was carried out in Kwara State of Nigeria. The state is bounded by Niger State in the northern part, Kogi State in the East and Osun, Oyo and Ekiti State in the South and Republic of Benin in the West. It is located in the forest savanna and enjoys moderate dry and wet seasons, the state is noted for heavy rainfall within September and October. The major occupation of people in the areas is farming. Rice, sorghum, cassava, maize, yam, beans and sweet potatoes are the major crops grown in the areas. The study was conducted on Olam Out-growers in Patigi and Edu Local Government Areas of Kwara State, which are the largest rice-producing communities in the State (Kwara ADP, 2015). The primary data which was used for this study was obtained through a structured interview schedule administered by personal interview. A list of small-holder farmers (farmers with less than 5 hectares of farmland) who participated in the Olam Out-growers scheme (contract farming) was obtained from Kwara ADP. A sample of 150 respondents (rice farmers) were selected from the ADP list.

The various analytical tools employed for this study include; Descriptive Statistics, Gross Margin, Production efficiency, stochastic frontier production function model. Descriptive statistics which include frequencies, percentages, means, mode and range, ratios were used to capture the demographic and socioeconomic characteristics of the respondents. 
Gross margin was used to determine the cost and return of rice in Olam Out-growers contract farming.

Gross margin $=$ Total Revenue - Total Variable Cost.

Net - Income $=$ Gross margin - Total Fixed Cost.

The production efficiency model is being used to determine the land productivity level of rice farmers in contract farming.

Land productivity level $=$ Total output/Total Farm Size (hectares).

The major tool of analysis used in this study was the stochastic frontier model by Battese and Coelli (1995). The stochastic frontier production function model is specified in the implicit form as follows:

$Y i=f(X i, \beta)+(V i-U i)$

Where: $Y_{i}$ is the output of the $i^{\text {th }}$ farm

$X_{i}$ is a $k x I$ vector of input quantities of the $i^{\text {th }}$ farm

$\beta$ is a vector of unknown parameters to be estimated

$V_{i}$ are random variables which are assumed to be normally distributed $\mathrm{N}\left(0, \delta_{\mathrm{v}}{ }^{2}\right)$ and independent of the $U_{i}$. It is assumed to account for measurement error and other factors not under the control of the farmer. $U_{i}$ are non-negative random variables, called technical inefficiency effects (Aigner et al., 1977).

A Cobb-Douglas Production form of the frontier used for this study is presented as follows:

$\ln Y=\beta_{0}+\beta_{1} \ln X_{1}+\beta_{2} \ln X_{2}+\beta_{3} \ln X_{3}+\beta_{4} \ln X_{4}+\beta_{5} \ln X_{5}+\beta_{6} \ln X_{6}+\beta_{7} \ln X_{7}+\beta_{8} \ln X_{8}+V_{i}-U_{i}$ (v)

Where: $Y=$ Crop (Rice) Output

$X_{1}=$ Quality of rice seed $(\mathrm{kg}), X_{2}=$ organic manure $(\mathrm{kg}), X_{3}=$ Fertilizer $(\mathrm{kg})$,

$X_{4}=$ Family Labour (man-day), $X_{5}=$ Hired Labour(man-day), $X_{6}=$ Farm size (ha), $X_{7}=$ Herbicide (liter), $X_{8}=$ Pesticides (litre)

$\beta_{0}, \beta_{1}, \beta_{2}, \beta_{3}, \beta_{4}, \beta_{5}, \beta_{6}, \beta_{7}=$ Parameters to be estimated.

The inefficiency model is represented by $U_{i}$ which is defined as follows:

$U_{i}=d_{0}+d_{1} z_{1}+d_{2} z_{2}+d_{3} z_{3}+d_{4} z_{4}+\ldots .+d_{n} z_{n}$

$\mathrm{U}_{\mathrm{i}}=$ Technical inefficiency

$\mathrm{z}_{1}=$ Age (years), $\mathrm{z}_{2}=$ Household size (number), $\mathrm{z}_{3}=$ Education status(number of year), $\mathrm{z}_{4}=$ Primary occupation $z_{5}=$ Farming experience (years), $z_{6}=$ Extension assess $\left(Y e s=1, \mathrm{~N}_{0}=0\right.$ )

$d_{0}, d_{1}, d_{2}, \ldots, d_{7}=$ Parameters to be estimated.

Since the dependent variable of the inefficiency model represents the mode of inefficiency. Battese and Coelli (1995) proposed a stochastic production function, which has firm's effects as a 
truncated normal random variable, in which the inefficiency effects are directly influenced by a number of variables.

\section{RESULTS AND DISCUSSION \\ Socio-economic Characteristics of the Respondents}

Result in Table 1 shows that $92 \%$ of the respondents were male while the remaining $8 \%$ were female. This shows that both male and female are involved in rice production in the study area. The higher proportion of male compared to female may be due to the energy demanding nature of agriculture which puts the male gender at a better advantage over the female counterpart. As shown in Table 1, the majority (94.7\%) of the farmers were married. This may not be connected with the fact that being married vis-à-vis child bearing implies more hands on the farm. The rest were either single, widowed or divorced.

Table 1 show that the modal class of household size was 8 in which the average household size ranges between 5-13 people in the study area. The house-hold size is a good determinant of the family labour. Since, the house-hold composition would determine the number and effectiveness of the farm family labour.

As shown in Table 1, about $30 \%$ of the farmers had one hectare of land, while about $10.7 \%$ of them farm on two hectare of land. Few of the farmers farm on 3-4 hectare of land. Table 1 shows that about $46 \%$ of the respondents had primary education, $42 \%$ had no formal education while $12 \%$ of the respondents had secondary education. This suggests that fair majority or more than half of the respondents were educated. About $50 \%$ of the respondents claimed farming as their primary occupation. While others were either civil servant, Trader, Livestock farmers or charcoal producers.

Most of the respondents, about $81.3 \%$, have their source of fund being raised by themselves, while the remaining respondent source for fund either through friends or relatives, or through a cooperative society. About $77.3 \%$ of the respondents used both family labour and hired labour, which are being used to bring about higher efficiency and increase in the production level of the farmers. Family labour appears to be the cheapest and readily available labour sourced for farm operations. Most of the farmers have the possession of their farm land through inheritance, accounting for about $74.7 \%$ of the respondents, while about $13.3 \%$ of the respondents purchased their farm land and about $12 \%$ of them were on a lease. Most $(71.3 \%)$ of the rice farmers got their farm inputs through Olam Out-growers/government intervention Agricultural Development Project (ADP), while $26 \%$ of the rice farmers got their inputs through FADAMA in the study area, as shown in Table 1. 
Table 1 shows that $100 \%$ of the respondents have access to extension agent, and about $55.3 \%$ of them have at least two extension officers contact per month. Also, Table 1 shows that all the respondents belong to one farmers' association or the other, as this is one of the criteria of the contract farming terms, which was in tandem with (Akanbi et al., 2011) that cooperative organization affords members the advantage of benefits accruing to members. The modal class for farming experience among the rice farmers that participated in the scheme in the study area ranges between 11-15 years, this result corroborates the Akanbi et al. (2011) that typical farmers at the study area had 15 years of farming experience.

Table 1: Socio-economic characteristics of farmers

\begin{tabular}{lll}
\hline Characteristics & Frequency (F) & Percentage (\%) \\
\hline Gender & 138 & \\
Male & 12 & 92.0 \\
Female & & 8.0 \\
Age (Years) & 7 & \\
$0-30$ & 22 & 4.7 \\
$31-40$ & 75 & 14.7 \\
$41-50$ & 40 & 50.0 \\
$51-60$ & 6 & 26.6 \\
61 -above & & 4.0 \\
Marital Status & 4 & \\
Single & 142 & 2.7 \\
Married & 4 & 94.7 \\
Others & & 2.7 \\
Household Size & 10 & \\
$5-6$ & 75 & 6.7 \\
$8-9$ & 39 & 50.0 \\
10-11 & 26 & 26.0 \\
12-13 & & 17.3 \\
Education Level & 63 & \\
No formal education & 69 & 42.0 \\
Primary education & 18 & 46.0 \\
Secondary education & & 12.0 \\
Primary Occupation & 75 & 50.0 \\
Crop production & 5 & 3.3 \\
Civil service & 15 & 10.0 \\
Trading & 47 & 31.6 \\
Livestock & 8 & 5.7 \\
Charcoal production & & \\
Farm size (Hectares) & 78 & 52.0 \\
$0.4-0.8$ & &
\end{tabular}




\begin{tabular}{|c|c|c|}
\hline $1.0-1.2$ & 47 & 31.3 \\
\hline $2.0-3.0$ & 17 & 11.4 \\
\hline$\geq 4$ & 8 & 5.3 \\
\hline \multicolumn{3}{|l|}{ Sources of fund } \\
\hline Personal saving & 122 & 81.3 \\
\hline Friends or relatives & 24 & 16.0 \\
\hline Co-operatives & 4 & 2.7 \\
\hline \multicolumn{3}{|l|}{ Source of labour } \\
\hline Family labour & 5 & 3.3 \\
\hline Hired labour & 29 & 19.3 \\
\hline Family and hired labour & 116 & 77.3 \\
\hline \multicolumn{3}{|l|}{ Farmers association } \\
\hline Farmers group or co-operative & 150 & 100 \\
\hline Nil & 0 & 0 \\
\hline \multicolumn{3}{|l|}{ Farmland } \\
\hline Inherited & 112 & 74.7 \\
\hline Purchase & 20 & 13.3 \\
\hline Leased & 18 & 12.0 \\
\hline \multicolumn{3}{|l|}{ Sources of input } \\
\hline Owned farm & 3 & 2.0 \\
\hline OLAM assisted ADP & 107 & 71.3 \\
\hline FADAMA & 39 & 26.0 \\
\hline Others & 1 & 0.7 \\
\hline \multicolumn{3}{|l|}{ Access to extension } \\
\hline Access & 150 & 100 \\
\hline Nil & 0 & 0 \\
\hline \multicolumn{3}{|c|}{$\begin{array}{l}\text { Number of Extension Contact } \\
\text { (past } 1 \text { years) }\end{array}$} \\
\hline 1 & 3 & 2.0 \\
\hline 2 & 83 & 55.3 \\
\hline 3 & 55 & 36.7 \\
\hline 4 & 8 & 5.3 \\
\hline 6 & 1 & 0.7 \\
\hline \multicolumn{3}{|l|}{ Farming experience (Years) } \\
\hline $0-5$ & 5 & 3.3 \\
\hline $6-10$ & 35 & 23.3 \\
\hline $11-15$ & 46 & 30.7 \\
\hline $16-20$ & 41 & 27.3 \\
\hline 21-above & 23 & 15.3 \\
\hline
\end{tabular}

Source: Field Survey, 2015. 


\section{Cost and Returns to Rice Production}

The costs and returns to the production of rice in contract farming in the study area is presented in Tables $2 \& 3$. Table 2 shows the summary of the variable costs incurred in the production of one hectare of land for rice production under of OLAM out-grower scheme in Edu and Patigi LGAs of Kwara State. The table shows that labour cost carries the highest with $\$ 61,353.54$ out of all the cost incurred which amounted to $\mathbf{N} 123,482.41$ as the total variable cost.

Table 2: Summary of costs and returns to production of one hectare of rice farm

\begin{tabular}{ll}
\hline Variable cost & Amount (A) \\
\hline Labour & $61,353.54$ \\
Seed & $2,987.00$ \\
Chemical & $3,303.53$ \\
Herbicide & $3,141.67$ \\
Organic manure & $4,050.00$ \\
Fertilizer & $48,646.67$ \\
Total variable cost (TVC) & $123,482.41$ \\
\hline
\end{tabular}

\section{Source: Field Survey, 2015}

Table 3 shows the profitability of rice production under the scheme. Apart from the variable costs incurred, a total fixed cost of $\mathrm{A} 5,621.43$ was incurred per hectare. A gross margin of $\mathrm{A} 250,483.99$ per hectare was obtained from rice production by the farmers. Further analysis also shows that a

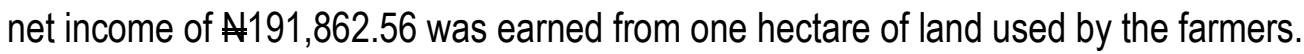

Table 3: Profitability of Rice Production under the Scheme

\begin{tabular}{|c|c|}
\hline Items & Calculation \\
\hline $\begin{array}{l}\text { Total Fixed Cost(TFC) (Worth of Land used in } \\
\text { naira covers the fixed cost) }\end{array}$ & $\$ 5,621.43$ \\
\hline Total Output & $752.265 \mathrm{~kg} / 0.375 \mathrm{ha}=2006.04 \mathrm{~kg} / \mathrm{ha}$ \\
\hline Price per unit of output & A160 \\
\hline Total Revenue(TR) & $(2006.04 * 160)=\mathrm{A} 320,966.40 / \mathrm{ha}$ \\
\hline Gross Margin $=T R-T V C$ & N $320,966.40-\mathrm{N} 123,482.41$ \\
\hline Gross Margin & A $197,483.99$ \\
\hline Net-Income $=$ Gross Margin - Total Fixed Cost & A $197,483.99-A 5,621.43$ \\
\hline Net-Income & $\mathrm{A} 191,862.56$ \\
\hline
\end{tabular}

Source: Field Survey, 2015. 


\section{The Productivity Level}

The land productivity level of the farmer under contract farming scheme is shown below; Land Productivity (LP) =Total output/farm size

A typical rice farmer in the study area had a total output of $752.265 \mathrm{~kg}$ from 0.375 hectare. Thus, $\mathrm{LP}=752.265 / 0.375=2,006.04 \mathrm{~kg}$ per ha.

Therefore, the land productivity of rice farms by the beneficiaries was $2,006.04 \mathrm{~kg}$ per ha. This is relatively higher than the 1.9 metric tonnes which is the average yield per hectare in Nigeria, without any out-growers' farmers scheme in place (Daramola, 2013).

\section{The Technical Efficiency of the Rice Farm}

The result in Table 4 shows that estimated livelihood coefficient for quality of seeds, hired labour and farm size indicate positive value of $72.689,6.061$ and 433.374 respectively and these were statically significant at $1 \%$ level. Accordingly, an increase in the quantity of seeds by one percent from this Olam out-growers' scheme (contract farming) will cause an increase in resultant output by over 70 percent. Therefore, the access to quality rice seeds by participants in this scheme might be what led to the apparent increase in yield per hectare of rice cultivated through this scheme. This result was corroborated with that of Okoruwa and Ogundele (2006) which concluded that quality of seed planted was more important than just relative quantity. Also in tandem with the findings of the study of Rahji and Omotesho (2006) where seed was found as the largest contributor to rice production among rice farmers in Niger state, Nigeria.

The result also shows that an increment in hired labour by one percent will bring about an increase in output by 6 percent. On the contrary, the estimated MLE coefficient of organic manure, family labour, herbicide and pesticide in this scheme were negatively statistical significant by t-value of $-4.10,-4.46,-81.68$ and -20.89 respectively. This indicate an inverse relationship that exist between the use of inputs and the resultant output obtained. This is consistent with Nosiru, et al. (2014) who found rice farmers in Kaduna State to be inefficient in both managerial and technical allocation of resources in New Rice for Africa (NERICA) production. This simply means that, an increase of the input by one unit will cause reduction in total corresponding to the value in their respective percentages. This may be as a result of the fact that most of the households' members who are still at a very young age may not be able to contribute to labour supply. Since they are likely to be in school during the peak period of

agricultural production activities. This finding was in tandem to that of Okoruwa and Ogundele (2006) which stated that over utilization of some inputs did not suggest corresponding increase in yield more than proportionate increase in output. Also, the finding of this study on labour use, 
however runs in support to that of Omotesho, Muhammad-Lawal and Yusuf (2010) who found out that the amount of labour used was inversely related to the output of rice farmers in Kwara State, Nigeria.

\section{Determinants of Technical Inefficiency}

The finding shows in Table 5 that the coefficients of household size and year of farming experience from the scheme has positive t-value of 4.10 and 3.40 respectively which were statistically significant at $5 \%$ level. This means the years of farming experience will definitely lead to acquiring of adequate knowledge of farming and adoption of relevant ideas. This finding was in tandem with that of (Nwaru et al., 2004) that stated the higher the farming experience the more the farmer would have gained more knowledge and technical ideas on how to tackle farm production problems, and the higher would be his output and income. The fact that household size is positively related to technical inefficiency implies that as the number of household members increases, technical efficiency decreases. This is in contrast with (Onyenwweaku and Nwaru 2005), who observed that there was no significant relationship between household size and technical efficiency in rice production. The coefficient of age of the participants was negative by t-value of -2.91 at $5 \%$ significant level, probably much younger individual participated in the scheme. Likewise, the coefficient of Primary occupation and Extension contact were significantly negative by t-value -2.72 and -2.27 respectively at $5 \%$ level. The finding shows that the participants have other form of occupations in which rice farming may probably not be their primary occupation.

Table 4: Maximum livelihood estimates (MLE)

\begin{tabular}{lllll}
\hline Variables & Parameters & Coefficient & S.E & t-value \\
\hline Constant & $\beta_{0}$ & $572.28^{* * *}$ & 1.04 & 548.46 \\
Quality of seed & $\beta_{1}$ & $72.69^{* * *}$ & 1.84 & 39.73 \\
Organic manure & $\beta_{2}$ & $-9.53^{* * *}$ & 2.32 & -4.10 \\
Fertilizer & $\beta_{3}$ & 0.21 & 0.15 & 1.37 \\
Family labour & $\beta_{4}$ & $-14.83^{* * *}$ & 3.33 & -4.46 \\
Hired labour & $\beta_{5}$ & $6.06^{* * *}$ & 1.72 & 3.53 \\
Farm size & $\beta_{6}$ & $433.37^{* * *}$ & 1.00 & 432.79 \\
Herbicide & $\beta_{7}$ & $-86.31^{* * *}$ & 1.06 & -81.68 \\
Pesticides & $\beta_{8}$ & $-38.00^{* *}$ & 1.82 & -20.89 \\
\hline
\end{tabular}

${ }^{* * *}$ Significant at $1 \%$ level of probability

\section{Source: Data Analysis, 2015}


Table 5: Determinant of Technical Inefficiency

\begin{tabular}{lllll}
\hline Variables & Parameters & Coefficient & S.E & t-value \\
\hline Constant & $d_{0}$ & -0.85 & 1.04 & -0.82 \\
Age & $d_{1}$ & $-9.22^{* *}$ & 3.17 & -2.91 \\
Household size & $d_{2}$ & $8.61^{* *}$ & 2.10 & 4.10 \\
Education status & $d_{3}$ & 1.03 & 1.15 & 0.90 \\
Primary occupation & $d_{4}$ & $-6.32^{* *}$ & 2.32 & -2.72 \\
Farming experience & $d_{5}$ & $15.46^{* *}$ & 4.54 & 3.40 \\
Extension contact & $d_{6}$ & $-5.00^{* *}$ & 2.20 & -2.27 \\
Sigma-squared & $\left(\delta^{2}\right)$ & 148365.44 & 1.00 & 148365.19 \\
Gamma & $(\gamma)$ & 0.10 & 0.26 & 0.39 \\
\hline
\end{tabular}

${ }^{*}$ Significant at $5 \%$ level of probability

Source: Data Analysis, 2015

\section{CONCLUSION}

The study shows that most (92\%) of the respondents in the study area are male while the female counterparts are $8 \%$. Also, majority $(94.7 \%)$ of the farmers participated in the scheme are married. The modal household size for those that participated in the scheme was 8 . About $30 \%$ of the respondents have one hectare of land for rice production in the study area while very few of the respondents are using more than one hectare. Mostly $(71.3 \%)$ rice farmers got most of their inputs through this Olam out-growers' scheme while more than $26 \%$ of the respondents got their inputs through FADAMA programme in the state. The study revealed that, the scheme was viable for the participants because the cost and return shows that net income was $\$ 44,258.56$ and productivity level was $2,006.04 \mathrm{~kg} / \mathrm{ha}$. In addition, the finding shows that estimated maximum likelihood coefficient of quality of seeds, hired labour and farm size indicate positive value at $1 \%$ level. Therefore, an increase by $1 \%$ in all these variables will cause increment in output by their corresponding coefficient in percentage. Also, from the study the outcome of the determinant of the technical inefficiency confirmed that household size and year of farming experience were positive statistically significant at $1 \%$ level, which have positive impact on rice production in the study area.

\section{RECOMMENDATIONS}

Though the result from the study shows remarkable effect of the Olam contract farming scheme on the production of rice farms, yet more still needs to be done on rice production. Despite the contract farming scheme, the yield of 2.01 metric tonnes per hectare which was gotten from study area is still quite low when compared to 7.0 metric tonnes potential yield of rice in Nigeria 
(Daramola et al., 2010); this is also in spite of the fact that the government in Nigeria had been investing steadily in rice production in recent times, both at the federal and state government level (USDAWMT, 2018). However, in order to achieve the stated FAO standard, a necessary partnership with private contract farming outfits like Olam is recommended, as this will continue to trigger the farmers' access to improved rice seed varieties and the necessary technologies needed to boost farm yield. Priority should also be given to extension service provision in order to make the farmers aware of salient information on how to improve their rice yield and also produce on a sustainable yield level.

\section{REFERENCES}

Aigner, D. J., Lovell, C. A. K. and Schimidt, P. (1977). Formulation and Estimation of Stochastic Frontier Function Models. Journal of Econometrics, 6, 21- 37.

Akanbi, U.O., Omotesho, O.A. and Ayinde, O.E. (2011). Analysis of Technical efficiency of Rice farms in the Duku River Irrigation scheme Kwara State, Nigeria. Nigeria Journal of Agriculture, Food and Environment (NJAFE), 7(3), 65-72.

Battese, G.E. and Coelli, T.J. (1995). Inefficiency Effects in a Stochastic Frontier production Function for Panel Data. Empirical Econometrics, 20, 325 - 332.

Bijman, J. (2008). Contract farming in developing countries: an overview, Working Paper, Wageningen-University, Quarter-3. Available online at http://choicesmagazine.org/choices-magazine/theme-articles/current-issues-inagricultural-contracts/contract-farming-whats-in-it-for-smallholder-farmers-indeveloping-countries

Bolwig, S., Gibbon, P. and Jones, S. (2009). The Economics of Smallholder Organic Contract Farming in Tropical Africa, World Development, 37(6), 1094-1104.

Daramola, A. G. (2013). The Nigerian agriculture and economic development: the way forward. A paper presented at the 27th annual conference of Farm Management Association of Nigeria (FAMAN) held between 26th - 30th August, 2013 at University of Ilorin, Nigeria.

Daramola .F.S, Falaki A.A, Ayinde O.E. and Ojehomoh, V.E.T. (2013). Evaluation of the effects of climate change on rice production in Niger State, Nigeria. Ethiopian Journal of Environmental Studies and Management. 6(6), 763-773.

Da Silva, C. A. (2005). The Growing Role of Contract Farming in Agri-food Systems Development: Drivers, Theory and Practice, FAO, Rome.

Du, X; Lu, L., and Zilbermann, D. (2013). The Economics of Contract Farming: A Credit and Investment Perspective, Energy Biosciences Institute, Department of Agricultural and Resource Economics, UC Berkeley, Berkeley, CA 94720.

Eaton, C., Shepherd, A.W. (2001) Contract farming: Partners for Growth, FAO Agricultural Services Bulletin 145. 
Hamilton, N.D. (2008). Agricultural Contracting: A U.S. Perspective and Issues for India to Consider", in A. Gulat, P.K. Joshi and M. Landes (eds.), Contract Farming in India: A Resource Book. http://www.ncap.res.in/contract_\%20farming/. Accessed 18/7/2017.

Little, P. and Watts, M. (1994). Living Under Contract: Contract Farming and Agrarian Transformation in Sub-Saharan Africa, Wisconsin: University of Wisconsin Press.

Nwaru, J.C., Onyenweaku, C.E, Nwagbo, E.C. and Nwosu, A.C. (2004). Determinant of Rural Farm Loan Repayment: Implication for Rural Credit Markets Development in Imo State, Nigeria. Journal of Agriculture and Food Sciences, 2 (1), 57-67.

Nosiru, O.M.O., Rahji, M.A.Y., Ikpi, A.E. and Adenegan, K.O. (2014). Scale Efficiency and Determinants of productivity of New Rice for Africa (NERICA) farmers in Kaduna state, Nigeria. Agrosearch, 14(2), 113-128.

Olomola, A. S. (2010). Models of contract farming for pro-poor growth in Nigeria. IPPG Briefing Note, August 2010.

Onyenweaku, C.E. and Nwaru, J.C. (2005). Application of stochastic frontier production function to the measurement of tropical efficiency in food production in Imo State, Nigeria. The Nigerian Agricultural Journal, 36 (1), 1-12.

Prowse, M. (2012). Contract Farming in Developing Countries: A Review. The A Savoir collection, AFD's Research Department, 1-99. http://researche.afd.fr

Rahji, M.A.Y. and Omotesho, O.A. (2006). Technical Inefficiency and Competitiveness in Production: the case of rice farmers in Niger State, Nigeria. Agrosearch, 8 (1): 67-79.

Rehber, E. (2007). Contract Farming: Theory and Practice, ICFAI University Press, Hyderabad, India, Pp 174, ISBN: 81314062029788131406205.

Okoruwa V.O. and Ogundele O.O. (2006). Technical Efficiency Differentials in Rice production Technologies in Nigeria. Agric Research Paper 134, African Economics Research Consortium, Nairobi.

Swinnen, J. and Maertens, M. (2007). Globalization, privatization, and vertical coordination in food value chains in developing and transition countries. Agricultural Economics, 37(1), 89-102.

United Nations Conference on Trade and Development (UNCTAD) (2009). World Investment Report on Transnational Corporations, Agricultural Production and Development, UNCTAD/DIAE/2009, Geneva. 2018 United States Department of Agriculture World Markets and Trade Report

Will, M. (2013). Contract farming handbook: A practical guide for linking small-scale producers and buyers through business model innovation, Published by Deutsche Gesellschaft für Internationale Zusammenarbeit (GIZ) GmbH, Germany, 1-116. 